\title{
ANALISIS POTENSI RETRIBUSI RUMAH POTONG HEWAN PADA UPACARA RAMBU SOLO' DAN RAMBU TUKA' DI KABUPATEN TORAJA UTARA
}

\author{
Regina Sheren Silamba ${ }^{1}$, Lintje Kalangi ${ }^{2}$, Jessy D. L. Warongan ${ }^{3}$ \\ ${ }^{1,2,3}$ Fakultas Ekonomi dan Bisnis, Jurusan Akuntansi, Universitas Sam Ratulangi, Jl.Kampus Bahu, Manado \\ 95115, Indonesia \\ E-mail: rssilamba@gmail.com
}

\begin{abstract}
The area retribution is one of locally generated revenue. Retribution is compulsory payments of the people to the state due to the existence of certain services provided by the state for its individual population. Toraja cultural activities are still very actively conducted by the people, where every traditional ceremony involves slaughterhouses, which means the collection of retribution slaughterhouses. This research aims to find out the potential of Retribution of Slaughterhouses ini Toraja Utara District. The data used is the primary data sourced from the interview and the secondary data sourced from the realization of retribution of slaughterhouse in 2013-2016. The analysis taken is potency of slaughterhouse retribution analysis. The results of the analysis show that the livestock slaughterhouse abattoir outside the slaughterhouse is bigger than the slaughterhouse. The analysis show that at the ceremony Rambu Solo' and Rambu Tuka', Pudu buffalo and pigs have great potential in retribution collection. This is because in Toraja customs, animal slaughter is not done carelessly.
\end{abstract}

Keywords: Potential, Retribution of Slaughterhouse.

\section{PENDAHULUAN}

Retribusi adalah pembayaran wajib dari rakyat kepada Negara karena adanya jasa tertentu yang diberikan oleh Negara bagi penduduknya secara perorangan. Jasa tersebut dapat dikatakan bersifat langsung, yaitu hanya yang membayar retribusi yang menikmati balas jasa dari Negara. Sesuai dengan ketentuan perundang-undangan di Indonesia saat ini penarikan retribusi hanya dapat dipungut oleh pemerintah daerah. Jadi, retribusi yang dipungut di Indonesia dewasa ini adalah retribusi daerah. (Siahaan, 2016:5). Retribusi Rumah Potong Hewan adalah pelayanan penyediaan fasilitas rumah pemotongan hewan ternak termasuk pelayanan pemeriksaan kesehatan hewan sebelum dan sesudah dipotong, yang disediakan, dimiliki, dan atau dikelola oleh pemerintah daerah. Dikecualikan dari objek Retribusi Rumah Potong Hewan adalah pelayanan penyediaan fasilitas rumah pemotongan hewan ternak yang disediakan, dimiliki, dan atau dikelola oleh BUMN, BUMD, dan pihak swasta (Siahaan, 2016:631).

Budaya Indonesia diantaranya budaya Toraja khususnya Toraja Utara yang terdapat di Sulawesi Selatan merupakan salah satu kawasan yang menyimpan beragam kekayaan, baik yang bersifat kekayaan alam maupun kekayaan adat istiadat yang selalu mengisi ruang dalam aktifitas tradisional yang terdapat dalam masyarakat Toraja Utara. Adat istiadat adalah hal yang sangat penting di kehidupan masyarakat Tana Toraja. Bisa dikatakan masyarakat Tana Toraja tidak bisa dipisahkan dari adat istiadat yang mereka jalankan, adat istiadat yang telah diturunkan nenek moyang mereka ini sangat mereka junjung tinggi didalam kehidupan mereka sehari-hari, bahkan tidak sedikit masyarakat tana toraja akan melakukan hal apapun untuk menjalankan adat istiadat mereka ini termasuk mengesampingkan aturan-aturan agama yang mereka anut (Lidwina, 2016).

Kebudayaan tersebut merupakan keunikan adat istiadat oleh masing-masing daerah yang dijunjung tinggi, bahkan menjadi kebanggaan dan identitas tersendiri. Tana Toraja merupakan salah satu daerah yang unik dan terkenal dengan adat istiadatnya yaitu Rambu 
Tuka' (pesta syukuran) dan Rambu Solo' (pesta kematian) (Sirajuddin, 2013). Kegiatan budaya masih sangat aktif dilakukan oleh masyarakat Toraja, yang di mana setiap upacara ini pasti melibatkan rumah potong hewan, ini berarti Retribusi Rumah Potong Hewan di Kabupaten Toraja Utara layak dan penting untuk diteliti.

Dari latar belakang masalah yang telah diuraikan, maka penulis merumuskan masalah yang akan dibahas yaitu bagaimana potensi Retribusi Rumah Potong Hewan pada upacara Rambu Solo' dan Rambu Tuka' di Kabupaten Toraja Utara?

Tujuan penelitian untuk mengetahui potensi Retribusi Rumah Potong Hewan di Kabupaten Toraja Utara.

\section{TINJAUAN PUSTAKA}

\subsection{Pengertian Akuntansi}

Akuntansi adalah pengukuran, penjabaran, atau pemberian kepastian mengenai informasi yang akan membantu manajer, investor, otoritas pajak dan pembuat keputusan lain untuk membuat alokasi sumber daya keputusan di dalam perusahaan, organisasi, dan lembaga pemerintah. Secara umum, akuntansi dapat didefinisikan sebagai informasi yang memberikan laporan kepada pengguna informasi akuntansi atau kepada pihak-pihak yang memiliki kepentingan (stakeholder) terhadap hasil kinerja dan kondisi keuangan perusahaan (Hery, 2014:1).

Akuntansi merupakan sistem informasi yang menyediakan laporan bagi para pihak pengambil keputusan (stakeholder) mengenai aktivitas ekonomi dan kondisi perusahaan. Di dalam penerapannya, akuntansi mengikuti prinsip-prinsip akuntansi yang berlaku secara umum, sehingga memungkinkan para stakeholder untuk membandingkan kinerja perusahaan dengan perusahaan lain yang sejenis. Proses akuntansi dimulai adanya transaksi, yaitu peristiwa yang dapat mengakibatkan berubahnya posisi keuangan perusahaan. Transaksi inilah yang menjadi atensi Pemerintah dalam mengeluarkan peraturan-peraturan perpajakan agar dapat memungut pajak atas transaksi untuk membiayai pembangunan di Indonesia. Dengan adanya titik ketersinggungan akuntansi dan pajak ini, yaitu transaksi, perusahaan cenderung menerapkan akuntansi yang sudah sesuai dengan peraturan pajak, atau disebut dengan istilah Akuntansi Pajak (Tax Accounting) (Lubis, 2015:2).

\subsection{Pengertian Retribusi Daerah}

Pengertian Retribusi pada umumnya mempunyai hubungan langsung dengan kembalinya prestasi, karena pembayaran tersebut ditujukan semata-mata untuk mendapat suatu prestasi tentu dari pemerintah, misalnya pembayaran retribusi parkir, retribusi sampah, dan lain-lain (Sumarsan, 2013:6). UU Nomor 28 Tahun 2009 tentang Pajak Daerah dan Retribusi Daerah menyebutkan bahwa Retribusi Daerah, yang selanjutnya disebut Retribusi, adalah pungutan Daerah sebagai pembayaran atas jasa atau pemberian izin tertentu yang khusus disediakan dan/atau diberikan oleh Pemerintah Daerah untuk kepentingan orang pribadi atau Badan.

\subsection{Subjek Retribusi Daerah}

Menurut Mardiasmo (2016:20), subjek Retribusi Daerah adalah sebagai berikut:

1. Retribusi Jasa Umum adalah orang pribadi atau badan yang menggunakan/menikmati pelayanan jasa umum yang bersangkutan.

2. Retribusi Jasa Usaha adalah orang pribadi atau badan yang menggunakan/menikmati pelayanan jasa usaha yang bersangkutan.

3. Retribusi Perizinan Tertentu adalah orang pribadi atau badan yang memperoleh izin tertentu dari Pemerintah Dearah. 


\subsection{Pengertian Retribusi Rumah Potong Hewan}

Pada Peraturan Daerah Kabupaten Toraja Utara Nomor 15 tahun 2011 pasal 1 ayat (10) tentang Retribusi Rumah Potong Hewan bahwa, Retribusi Rumah Potong Hewan yang selanjutnya dapat disebut Retribusi adalah pembayaran atas pelayanan jasa atau fasilitas rumah potong hewan dan tempat pemotongan hewan di luar rumah potong hewan yang diizinkan oleh pemerintah termasuk pemeriksaan kesehatan hewan sebelum dan sesudah dipotong yang disediakan atau dikelola oleh Pemerintah Daerah.

\subsection{Potensi}

Menurut Kamus Besar Bahasa Indonesia (KBBI), potensi adalah kemampuan yang mempunyai kemungkinan untuk dikembangkan; kekuatan; kesanggupan; daya. Karena potensi bersifat tersembunyi, maka perlu diteliti besarnya potensi yang ada termasuk potensi pendapatan, dan mengidentifikasi faktor-faktor yang mempengaruhi pendapatan sebagai bagian dari upaya mengenali potensi.

\subsection{Potensi Retribusi Rumah Potong Hewan}

Potensi pendapatan Retribusi Rumah Potong Hewan yang dilaksanakan di luar rumah potong hewan dapat dihitung berdasarkan jumlah pesta dikali dengan rata-rata jumlah hewan ternak yang dipotong dikali dengan tarif yang diberlakukakan dalam Peraturan Daerah Kabupaten Toraja Utara Nomor 15 Tahun 2011. Jumlah pesta dan hewan ternak yang dipotong dapat mempengaruhi pendapatan. Semakin banyak pesta yang dilaksanakan dan semakin banyak ternak yang dikurbankan maka potensi penerimaan retribusi rumah potong hewan juga bertambah atau meningkat dari jumlah pemungutan sebelumnya.

\section{METODE PENELITIAN}

\subsection{Jenis Penelitian}

Dalam penelitian ini penulis menggunakan jenis penelitian kualitatif dimana jenis penelitian ini adalah bersifat deskriptif. Penelitian deskriptif diartikan sebagai suatu penelitian yang berusaha mendeskripsikan suatu fenomena/peristiwa secara sistematis sesuai dengan apa adanya. Penelitian deskriptif dilakukan untuk memperoleh informasi mengenai keadaan saat ini. Dalam penelitian semacam itu, peneliti mencoba menentukan sifat situasi sebagaimana adanya pada waktu penelitian dilakukan. Dalam studi deskriptif tidak ada kontrol perlakuan seperti dalam studi eksperimen karena tujuannya adalah menggambarkan "apa adanya" berkaitan dengan variabel-variabel atau kondisi-kondisi dalam situasi. Penelitian deskriptif pada umumnya tidak diarahkan untuk pengujian hipotesis (Dantes, 2012:51).

\subsection{Tempat dan Waktu Penelitian}

Penelitian ini dilakukan di Kabupaten Toraja Utara tepatnya pada instansi yang terkait dengan permasalahan yaitu Dinas Pendapatan Pengelola Keuangan dan Aset Daerah (DPPKAD) dan Dinas Pertanian, Peternakan, dan Perikanan. Instansi ini dipilih karena merupakan sumber data maupun informasi yang dibutuhkan dari permasalahan. Adapun waktu penelitian yang dilapkukan selama bulan April-Agustus 2017.

\subsection{Jenis \& Sumber Data}

Menurut Sugiyono (2016:6), terdapat dua jenis data dalam penelitian yaitu:

1. Data Kualitatif adalah data yang berbentuk kata, kalimat, gerak tubuh, ekspresi wajah, bagan, gambar dan foto (Sugiyono, 2016:6). Data kualitatif dalam penelitian ini adalah uraian keadaan dan lingkungan objek serta hasil wawancara. 
2. Data Kuantitatif adalah data yang berbentuk angka atau data kualitatif yang diangkaka/scoring (Sugiyono, 2016:6). Data kuantitatif dalma penelitian ini adalah data yang didapat dari dokumen berupa laporan penerimaan Retribusi Rumah Potong Hewan di luar rumah potong hewan pada DPPKAD dan Retribusi Rumah Potong Hewan di dalam rumah potong hewan pada Dinas Pertanian, Peternakan, dan Perikanan Kabupaten Toraja Utara dengan perhitungan menggunakan rumus matematika sederhana.

Menurut Sunyoto (2016:21) sumber data penelitian terdapat dua sumber data yang dipakai, yaitu:

1. Data Primer

Data primer adalah data yang dikumpulkan langsung dari hasil wawancara dengan informan yang dianggap berpotensi dalam memberikan informasi yang relevan. Pada umum data primer ini sebelumnya belum tersedia, sehingga seorang peneliti harus melakukan pengumpulan sendiri data ini berdasarkan kebutuhannya.

2. Data Sekunder

Data sekunder adalah data yang bersumber dari catatan yang ada pada perusahaan dan dari sumber lainnya yaitu dengan mengadakan studi kepustakaan dengan mempelajari buku-buku yang ada hubungannya dengan objek penelitian atau dapat dilakukan dengan menggunakan data dari Biro Pusat Statistik (BPS).

Keduanya sumber data tersebut digunakan dalam penelitian ini.

\subsection{Teknik Pengumpulan Data}

Teknik pengumpulan data merupakan teknik atau cara mengumpulkan data yang dibutuhkan untuk menjawab rumusan masalah penelitian. Untuk mengumpulkan data peneliti menggunakan teknik :

1. Wawancara

Wawancara merupakan salah satu teknik pengumpulan data yang dilakukan dengan berhadapan secara langsung dengan yang diwawancarai tetapi dapat juga diberikan daftar pertanyaan dahulu untuk dijawab pada kesempatan lain (Noor, 2011:138).

2. Dokumen

Sebagian besar fakta dan data tersimpan dalam bahan yang berbentuk dokumentasi. Sebagian besar data yang tersedia yaitu berbentuk surat, catatan harian, cendera mata, laporan, artefak, dan foto. Sifat utama data ini tak terbatas pada ruang dan waktu sehingga memberi peluang kepada peneliti untuk mengetahui hal-hal yang pernah terjadi di waktu silam (Noor, 2011:141).

\section{HASIL ANALISIS DAN PEMBAHASAN}

4.1. Hasil Analisis

\section{1) Pelaksanaan Pemungutan Retribusi Rumah Potong Hewan di Kabupaten Toraja Utara}

Retribusi Rumah Potong Hewan merupakan salah satu sumber Pendapatan Asli Daerah di Kabupaten Toraja Utara. Dalam wawancara dengan Kepala Bidang Pendaftaran diketahui bahwa pelaksaan pemungutan Retribusi Rumah Potong Hewan telah sesuai dengan prosedur yang telah ditetapkan dalam Peraturan Daerah Nomor 15 tahun 2011 tentang Retribusi Rumah Potong Hewan.

Adapun prosedur pemungutan RRPH yang sesuai dengan Peraturan Daerah Toraja Utara Nomor 15 tahun 2011 tentang Retribusi Rumah Potong Hewan, yaitu :

1. Kolektor Kecamatan mengambil karcis retribusi yang telah diporporasi oleh Badan Pendapatan Daerah. 
2. Jika ada pesta Rambu Solo/Rambu Tuka'di Kelurahan/Lembang, kolektor Kelurahan/Lembang mengambil karcis retribusi di Kecamatan melalui kolektor Kecamatan.

3. Retribusi yang diterima dari masing-masing Kelurahan/Lembang disetor langsung oleh kolektor Kelurahan/Lembang ke kolektor Kecamatan.

4. Kolektor Kecamatan menyetor retribusi ke DPPKAD melalui Bendahara Bapenda.

5. Bendahara menyetor retribusi tersebut ke Bank Pembangunan dalam kurun waktu 24 jam.

Walaupun telah sesuai dengan prosedur tetapi, dalam pelaksanaan pemungutan Retribusi Rumah Potong Hewan masih ditemukan kendala, yaitu adanya penunggakan pembayaran retribusi. Disamping itu, sanksi terhadap penunggakan tidak diberlakukan.

Ternak yang dipotong di luar rumah potong hewan dianggap sudah diperiksa. Petugas dari Dinas Peternakan hanya memantau saja pada saat hewan dipotong di upacara adat Rambu Solo' dan Rambu Tuka'. Agar tidak mengganggu atau mengulur waktu susunan upacara.

Bagi Wajib Retribusi yang tidak mendaftarkan ternaknya untuk dipungut retribusi, dianggap tidak ada atau tidak terdaftar.

\section{2) Analisis Potensi Penerimaan Retribusi Rumah Potong Hewan}

Besarnya jumlah pesta mempengaruhi tingkat potensi penerimaan Retribusi Rumah Potong Hewan di luar rumah potong hewan di Kabupaten Toraja Utara. Berikut jumlah pesta Rambu Solo' dan Rambu Tuka' di Kabupaten Toraja Utara pada tahun 2013-2016.

Tabel 1

Jumlah Pesta Rambu Solo' dan Rambu Tuka' Kabupaten Toraja Utara tahun 2013-2016

\begin{tabular}{|l|l|l|l|}
\hline TAHUN & RAMBU SOLO' & RAMBU TUKA' & TOTAL \\
\hline 2013 & 1048 & 170 & 1218 \\
\hline 2014 & 1056 & 169 & 1225 \\
\hline 2015 & 983 & 220 & 1203 \\
\hline 2016 & 1166 & 200 & 1366 \\
\hline
\end{tabular}

Sumber: DPPKAD Kabupaten Toraja Utara dan diolah 2017

Potensi retribusi Rumah Potong Hewan yang dilakukan di luar rumah potong hewan yaitu pada upacara Rambu Solo' dan Rambu Tuka' di Kabupaten Toraja Utara tahun 20132016 dapat dihitung berdasarkan jumlah pesta setiap tahunnya. Pada upacara Rambu Solo' dan Rambu Tuka', ternak yang umum dan banyak dikurbankan yaitu kerbau pudu dan babi. Karena pada adat Toraja, pemotongan ternak tidak sembarang dilakukan. Kecuali kerbau $p u d u$ dan babi, tidak memiliki aturan untuk dipotong. Berikut perhitungan potensi Retribusi Rumah Potong Hewan di luar rumah potong hewan khususnya kerbau pudu dan babi. 


\section{Tabel 2}

Potensi Retribusi Rumah Potong Hewan pada Upacara Rambu Solo' dan Rambu Tuka' di Kabupaten Toraja Utara Tahun 2013-2016

\begin{tabular}{|c|c|c|c|c|c|}
\hline Tahun & Jenis Hewan & Tarif & Banyaknya Pesta & Rata-rata & Potensi \\
\hline \multirow[t]{2}{*}{2013} & Kerbau Pudu & Rp 200,000 & 1218 & 6 & Rp $1,461,600,000$ \\
\hline & Babi & Rp 75,000 & 1218 & 20 & Rp $1,827,000,000$ \\
\hline \multirow[t]{2}{*}{2014} & Kerbau Pudu & $\operatorname{Rp} 200,000$ & 1225 & 6 & $\operatorname{Rp} 1,470,000,000$ \\
\hline & Babi & Rp $\quad 75,000$ & 1225 & 22 & Rp 2,021,250,000 \\
\hline \multirow[t]{2}{*}{2015} & Kerbau Pudu & Rp 200,000 & 1203 & 6 & Rp $1,443,600,000$ \\
\hline & Babi & Rp 75,000 & 1203 & 22 & Rp $1,984,950,000$ \\
\hline \multirow[t]{2}{*}{2016} & Kerbau Pudu & Rp 200,000 & 1366 & 6 & Rp $1,639,200,000$ \\
\hline & Babi & Rp 75,000 & 1366 & 23 & $\operatorname{Rp} 2,356,350,000$ \\
\hline
\end{tabular}

Berdasarkan tabel 2, perhitungan potensi Retribusi Rumah Potong Hewan berdasarkan jumlah pesta bahwa pada tahun 2013 potensi retribusi kerbau pudu Rp1,461,600,000.00 dan babi Rp1,827,000,000.00, tahun 2014 potensi retribusi kerbau pudu Rp1,470,000,000 dan babi Rp2,021,250,000.00, tahun 2015 potensi retribusi kerbau pudu Rp1,443,600,000.00 dan babi Rp1,984,950,000.00, dan tahun 2016 potensi retribusi kerbau рudu Rp1,639,200,000.00 dan babi Rp2,356,350,000.00.

Tabel 3

Realisasi Penerimaan Retribusi Rumah Potong Hewan di Luar Rumah Potong Hewan Khususnya Kerbau Pudu dan Babi

\begin{tabular}{|l|l|l|l|c|}
\hline Tahun & Jenis Hewan & Tarif & Jumlah Hewan & Realisasi \\
\hline 2013 & Kerbau Pudu & $\operatorname{Rp~200,000}$ & 7.822 & Rp 1,564,400,000 \\
\hline & Babi & $\operatorname{Rp~75,000~}$ & 24.356 & Rp 1,826,700,000 \\
\hline 2014 & Kerbau Pudu & $\operatorname{Rp~200,000~}$ & 7.327 & Rp 1,465,400,000 \\
\hline & Babi & $\operatorname{Rp~75,000~}$ & 26.529 & Rp 1,989,675,000 \\
\hline 2015 & Kerbau Pudu & $\operatorname{Rp~200,000~}$ & 7.069 & Rp 1,413,800,000 \\
\hline & Babi & $\operatorname{Rp~75,000~}$ & 26.582 & Rp 1,993,650,000 \\
\hline 2016 & Kerbau Pudu & $\operatorname{Rp~200,000~}$ & 8.065 & Rp 1,613,000,000 \\
\hline & Babi & $\operatorname{Rp~75,000~}$ & 31.081 & Rp 2,331,075,000 \\
\hline
\end{tabular}

Sumber: DPPKAD Kabupaten Toraja Utara dan diolah 2017

Berdasarkan tabel 3, dapat dilihat bahwa perhitungan realisasi penerimaan Retribusi Rumah Potong Hewan di luar rumah potong pada tahun 2013 realisasi kerbau pudu sebesar

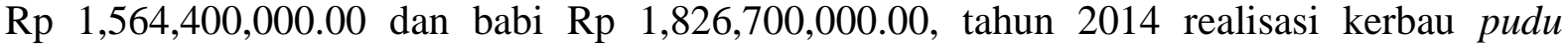
sebesar Rp1,465,400,000.00 dan babi Rp1,989,675,000.00, tahun 2015 realisasi kerbau pudu sebesar Rp1,413,800,000.00 dan babi Rp1,993,600,000.00, dan tahun 2016 realisasi kerbau pudu sebesar Rp1,613,000,000 dan babi Rp2,331,075,000.00. Pada tahun 2015 penerimaan Retribusi Rumah Potong Hewan di luar rumah potong hewan mengalami penurunan. Hal ini terjadi karena pesta yang diadakan tidak lebih dari tahun sebelumnya. 


\section{Tabel 4}

\section{Realisasi dan Potensi Penerimaan Retribusi Rumah Potong Hewan di Luar Rumah Potong Hewan Khususnya Kerbau Pudu dan Babi}

\begin{tabular}{|l|l|c|c|}
\hline Tahun & Jenis Hewan & Realisasi & Potensi \\
\hline 2013 & Kerbau Pudu & Rp 1,564,400,000 & Rp 1,461,600,000 \\
\hline & Babi & Rp 1,826,700,000 & Rp 1,827,000,000 \\
\hline 2014 & Kerbau Pudu & Rp 1,465,400,000 & Rp 1,470,000,000 \\
\hline & Babi & Rp 1,989,675,000 & Rp 2,021,250,000 \\
\hline 2015 & Kerbau Pudu & Rp 1,413,800,000 & Rp 1,443,600,000 \\
\hline & Babi & Rp 1,993,650,000 & Rp 1,984,950,000 \\
\hline 2016 & Kerbau Pudu & Rp 1,613,000,000 & Rp 1,639,200,000 \\
\hline & Babi & Rp 2,331,075,000 & Rp 2,356,350,000 \\
\hline
\end{tabular}

Sumber: DPPKAD Kabupaten Toraja Utara dan diolah 2017

Berdasarkan tabel 4, realisasi dan potensi penerimaan Retribusi Rumah Potong Hewan di luar rumah potong hewan khususnya kerbau pudu dan babi yang dihitung berdasarkan jumlah pesta dapat dilihat bahwa jumlah pesta mempengaruhi penerimaan Retribusi Rumah Potong Hewan. Kecuali kerbau pudu di tahun 2013 dan babi di tahun 2015, potensi lebih rendah dari realisasi.

\subsection{Pembahasan}

Penerimaan Retribusi Rumah Potong Hewan yang ada di Kabupaten Toraja Utara berbeda dengan Retribusi Rumah Potong Hewan di kota lainnya. Di Kabupaten Toraja Utara pemotongan hewanada 2 yaitu di dalam rumah potong hewan dan di luar rumah potong hewan. Pemotongan di luar rumah potong hewan berhubungan dengan adat istiadat Toraja. Pemotongan hewan di Toraja Utara merupakan suatu tradisi yang sampai saat ini masih dilakukan oleh masyarakat Toraja. Jika dibandingkan penerimaan retribusi di luar rumah potong hewan lebih banyak dari pada di dalam rumah potong hewan.

Dalam pelaksaanan pemungutan Retribusi Daerah khususnya Retribusi Rumah Potong Hewan, Pemerintah Daerah didasari dengan Undang-undang Nomor 28 Tahun 2011 tentang Pajak Daerah dan Retribusi Daerah, dan Peraturan Daerah Toraja Utara Nomor 15 Tahun 2011 tentang Retribusi Rumah Potong Hewan. Adanya peraturan tersebut pemungutan Retribusi Rumah Potong Hewan dapat berjalan dengan baik dan dapat meminimkan penerimaan retribusi.

Potensi retribusi rumah potong hewan pada saat upacara Rambu Tuka' dan Rambu Solo' berada pada jumlah hewan yang dikurbankan, semakin banyak jumlah hewan yang dikurbankan maka retribusi yang akan diterima juga akan semakin banyak. Tapi, ada ternak yang tidak didaftarkan oleh wajib retribusi untuk menghindari pemungutan retribusi pada saat upacara adat berlangsung. Hal ini dapat mengurangi pendapatan retribusi yang seharusnya didapatkan. Selain itu, jumlah retribusi yang diterima juga dipengaruhi oleh waktu pembayarannya. Jika retribusi dibayarkan langsung pada saat upacara berlangsung maka jumlah yang diterima juga akan lebih dari estimasi potensi, tetapi dari hasil wawancara yang didapatkan retribusi sering mengalami penunggakan pembayaran, dimana pembayaran seharusnya dilakukan paling lambat satu bulan setelah dilakukan pemotongan ternak sesuai dengan Peraturan Daerah Kabupaten Toraja Utara Nomor 15 Tahun 2011 tentang Retribusi Rumah Potong Hewan pasal 15 mengenai Tata Cara Pembayaran.

Penunggakan pembayaran retribusi pemotongan hewan pada upacara Rambu Solo' dan Rambu Tuka' salah satunya dilatarbelakangi oleh tingginya harga dari ternak yang akan dikurbankan. Harga ternak yang berada pada kisaran puluhan hingga ratusan juta menyebabkan masyarakat lebih memprioritaskan untuk melunasi ternak yang 
akandikurbankan demi berjalannya upacara daripada membayar retribusi ternak kurban. Pemerintah Daerah tidak memberlakukan sanksi kepada Wajib Retribusi yang menunggak sebagaimana yang tertulis dalam Perda Kabupaten Toraja Utara Nomor 15 Tahun 2011 tentang Retribusi Rumah Potong Hewan pasal 20 mengenai Sanksi Administrasi terhadap penunggakan pembayaran retribusi. Tapi pemerintah tetap melakukan pemeriksaan kembali pemungutan yang masih terutang sebagaimana tertulis dalam Undang-undang Nomor 28 Tahun 2009 pasal 1 ayat 75 mengenai pemeriksaan dan memberikan peringatan melalui Surat Tagihan Retribusi Daerah sebagaimana tertulis dalam Peraturan Daerah Nomor 15 Tahun 2011 pasal 13 ayat 2 tentang Penetapan Retribusi.

Meningkatnya penerimaan Retribusi Rumah Potong Hewan yang disebabkan karena faktor ekonomi, yaitu jika pendapatan meningkat maka kemampuan masyarakat untuk membayar pungutan retribusi yang ditetapkan oleh pemerintah meningkat dan kekayaan dari masing-masing keluarga yang biasanya membutuhkan banyak ternak yang akan dijadikan kurban pada saat pesta, faktor demografi berupa jumlah penduduk yang dapat mempengaruhi pendapatan dan faktor lainnya berupa kebiasaan adat sosial budaya yang dimana kebutuhan setiap daerah berbeda. Karena adat orang dalam pedalaman masih sangat kuat. Semakin banyak jumlah pesta yang dilaksanakan setiap tahun maka penerimaan Retribusi Rumah Potong Hewan akan bertambah. Hal ini dapat dilihat pada tabel 4.10 bahwa faktor ekonomi, faktor demografi, dan faktor lainnya dapat mempengaruhi penerimaan Retribusi Rumah Potong Hewan.

\section{KESIMPULAN DAN SARAN}

\subsection{Kesimpulan}

Berdasarkan hasil analisis dan pembahasan mengenai potensi Retribusi Rumah Potong Hewan pada upacara Rambu Solo' dan Rambu Tuka' dari tahun 2013-2016, dapat diambil kesimpulan sebagai berikut :

1. Potensi retribusi Rumah Potong Hewan di luar RPH lebih besar dari pada di dalam Rumah Potong Hewan.

2. Estimasi potensi penerimaan retribusi yang dilakukan di dalam rumah potong hewan pada tahun 2014 sebesar Rp 257,750/bulan dan tahun 2015 sebesar Rp 235,875/bulan. Variabel untuk menghitung potensi retribusi adalah jenis hewan ternak yang dipotong dikali dengan tarif sesuai dengan Peraturan Daerah.

3. Estimasi potensi penerimaan retribusi yang dilakukan di luar rumah potong hewan pada tahun 2013 sebesar Rp 92,108,625, tahun 2014 sebesar Rp 93,050,625, tahun 2015 sebesar Rp 90,785,625, dan tahun 2016 sebesar Rp 105,491,875. Variabel untuk menghitung potensi retribusi adalah jenis hewan ternak yang dipotong dikali dengan tarif sesuai dengan Peraturan Daerah.

4. Potensi Retribusi Rumah Potong Hewan di luar rumah potong hewan berdasarkan jumlah pesta khususnya pada ternak kerbau pudu dan babi pada tahun 2013 sebesar Rp 3,288,600,000, tahun 2014 sebesar Rp 3,491,250,000, tahun 2015 sebesar Rp 3,428,550,000 dan tahun 2016 sebesar Rp 3,995,550.

\subsection{Saran}

Berdasarkan hasil penelitian maka didapat diberikan saran sebagai berikut:

1. Kolektor harus memiliki strategi khusus bagi wajib retribusi dalam hal pemungutan Retribusi Rumah Potong Hewan yang mengadakan pesta, untuk meminimkan penerimaan retribusi. Strategi yang dimaksud, yaitu kolektor lebih efektif dalam pengawasan dan pendataan terhadap ternak yang dibawa oleh wajib retribusi untuk menghindari kecurangan-kecurangan yang terjadi dalam pelaksanaan pemungutan 
Retribusi Rumah Potong Hewan sehingga realisasi penerimaan retribusi pada tahun itu dapat melebihi realisasi penerimaan sebelumnya.

2. Lebih giat mengadakan sosialisasi pemungutan Retribusi Rumah Potong Hewan dan kegunaannya agar wajib retribusi mengetahui pentingnya membayar retribusi dan melaporkan ternak yang di bawa.

3. Menerapkan sanksi administrasi yang telah ditetapkan dalam Peraturan Daerah Kabupaten Toraja Utara Nomor 15 Tahun 2011 kepada wajib retribusi yang menunggak.

\section{DAFTAR PUSTAKA}

Abiola, James dan Moses Asiweh. 2012. Impact of Tax Administration on AGovernment Revenue in a Developing Economy-A Case Study of Nigeria. International Journal of Business and Social Science. Vol. 3 No. 8. Hal. 99-103.

Dantes, Nyoman. 2012. Metode Penelitian. Yogyakarta: Penerbit Andi.

Damayanti, Theresia Woro dan Supramono. 2015. Perpajakan Indonesia. Edisi II. Yogyakarta: Andi.

Juri, H. Mat. 2012. Analisis Kontribusi Pajak Daerah dan Retribusi Daerah Terhadap Pendapatan Asli Daerah (PAD) Kota. Jurnal Eksis. Politeknik Negeri Samarinda. ISSN: 0216-6437. Vol. 8 No. 1, Maret 2012. Hal. 2001-2181.

Kahayan, Yudhi Fajar. 2001. Potensi Pajak Hotel dan Restoran serta Potensi Retribusi Rumah Potong Hewan Di Kota Padang Panjang. Jurnal UGM. Universitas Gadjah Mada. Yogyakarta.

Lubis, Irsan. 2015. Mahir Akuntansi Pajak Terapan Berbasis Standar Akuntansi \& Ketentuan Pajak Terbaru. Yogyakarta: Andi.

Panggalo, Rafika Rante. 2015. Analisis Kontribusi dan Potensi Retribusi Rumah Potong Hewan Terhadap Pendapatan Asli Daerah Kabupaten Toraja Utara. Skripsi. Universitas Hasanuddin. Makassar.

Peraturan Daerah Kabupaten Toraja Utara Nomor 15 Tahun 2011 Tentang Retribusi Rumah Potong Hewan.

Sumarsan, Thomas. 2013. Perpajakan Indonesia. Edisi 3. Jakarta : Indeks.

Soemarso, 2016. Akuntansi Suatu Pengantar. Buku 1, Edisi 5. Jakarta : Salemba Empat.

T, Ade Natalia. 2008. Analisis Kontribusi Pajak Potong Hewan pada Upacara Adat Rambu Tuka dan Rambu Solo terhadap Pendapatan Asli Daerah Kabupaten Tana Toraja. Jurnal. Universitas Kristen Duta Wacana. Salatiga.

Undang-Undang Nomor 28 Tahun 2009 tentang "Pajak Daerah dan Retribusi Daerah".

Warnadi, Retnanda Kreshna. 2010. Kontribusi Retribusi Pemakainan Kekayaan Daerah Dibandingkan dengan Retribusi Rumah Potong Hewan Terhadap Pendapatan Asli Daerah Kota Surakarta. Tugas Akhir. Universitas Sebelas Maret. Surakarta.

Warren, Carl S., James M. Reeve, and Jonathan Duchac. 2017. Financial Accounting. $15^{\text {th }}$ ed. USA: Cengage Learning.

Yusuf, Nurmi dan Andi Aco Agus. 2016. Implementasi Peraturan Daera h Nomor 15 Tahun 2011 Tentang Retribusi Rumah Potong Hewan (Studi pada Upacara Adat Rambu Solo' Di Kecamatan Rantepao Kabupaten Toraja Utara). Jurnal Tomalebbi. Universitas Negeri Makassar. ISSN:2355-6439. Vol. 3 No. 1, Maret 2016. 